\title{
Analysis of highway project financing in Laos
}

\author{
Yajie Huang \\ International Business School \\ Yunnan University of Finance and Economics \\ Kunming, China \\ 534633894@qq.com
}

\author{
Ning Yan* \\ International Business School \\ Yunnan University of Finance and Economics \\ Kunming, China \\ ningyan68@126.com
}

\begin{abstract}
This article analyses a financial environment of Laos's country, furthermore the financing mode of Chinese enterprises investment in Laos and a brief analysis of China's investment situation that reinforce power for financial investments. In 2016 the total mileage of the National Highway in Laos has reached 43604 kilometers that represent: 866 kilometers of concrete road, 6496 kilometers of asphalt road, 15324 kilometers of gravel road, and 20919 kilometers of soil road. However Laos has more than $40,000 \mathrm{~km}$ highway included the gravel pavement and dirt road. Because of the insufficient road infrastructure the demand for road development has been increasing.
\end{abstract}

Keywords-highway in Laos; investment in Laos; Laos financing

\section{INTRODUCTION}

Guo and $\mathrm{Li}$ (2010) [6] point out to the currently situation of financial development in Laos. Phannakone (2012) [4] analyses the development of Chinese enterprises investing in highway project of Laos. Liu ( 2016) [5] examine investment and financing mode of transportation infrastructure in Laos.

In the background of "The Belt and Road", Chinese enterprises are speeding up the rate of "going out", thereby China has potential to strengthen the position in Europe to geographically connect Europe with the Asia Pacific Economic Circle. Laos as a neighbour of China has strategic significance to China's economic development, Laos as "the Belt and Road" along the country, remain still to be as a one of the poorest and most economically located infrastructure in Southeast Asia. In recent years China invest more in infrastructure of Laos to build, support and promote the connectivity as a geographically benefit to facilitate the transportation. The open question of financing is worth to study.

\section{RESEARCH OF LAOTIAN HIGHWAY INFRASTRUCTURE ON INVESTMENT AND FINANCING MODE}

\section{A. Source of funds}

National financial allocations of resources refers to the national financial revenue as the main source to fund the enterprises, including the state budget and local financial means to support the project construction as to provide the necessary financial capital. Because of the lack funds in

\footnotetext{
* Corresponding author
}

theLao the state financial investments are limited and the infrastructure transportation fall behind.

\section{B. Issue shares and bonds}

Companies can raise large amounts of money from the capital markets by issuing stocks and bonds to the community. Companies can raise large amounts of money from the capital markets by issuing stocks and bonds to the community. But only 5 stocks in the Lao stock market in 2016: LAO PUBLIC, EDL Generation Public Company, LAO WORLD PUBLIC COMPANY, Petroleum Trading Lao Public Company, Souvanny Home Center Public Company.

\section{Bank loans}

Laos's financial system is very poor. From Guo and $\mathrm{Li}$ (2010) [6], the Central Bank of Laos is the main organ of the head of the government, that is responsible for managing the state's banking operations concerning monetary credit, making monetary policy and supervising commercial banks. There are three commercial banks, which include state-owned commercial banks, private banks, joint venture banks, branches of foreign banks and foreign banks. Lao bank has less assets, single mode of operation and poor loan conditions.

The figure represents in Laos the high lending rate and the large loans costs. By comparing the lending rates in 2011 and 2015, LAK, USD and THB are declining. In 2015, the Laotian Central Bank reduced the loan costs of the business in order to promote investment against to reduce lending rates.

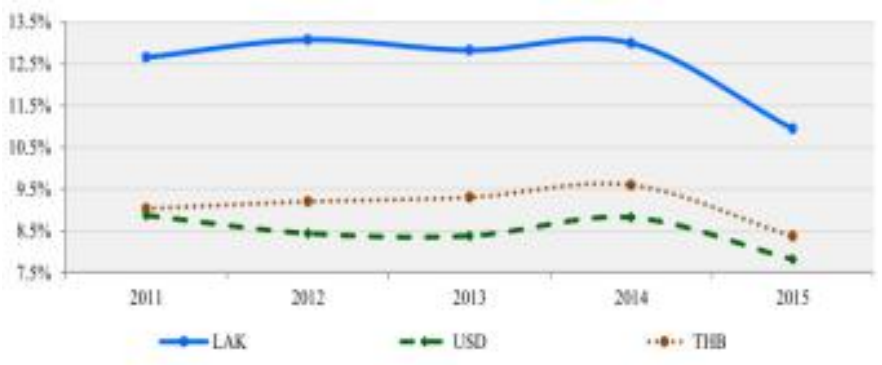

Sourte: Bank of the Lan PDR

Fig. 1. Lending rates in laos

\section{Civil loan}

Laos's civil loans refer to financing of non-financial institutions, generally public and private sector and the 
partnership to raise funds. As the Laos financial system is imperfect and economic policy is not standardized, formal financial institutions cannot fully meet the needs of enterprises.

\section{E. Foreign loans}

\section{1) Foreign government loans}

In general, loans from foreign governments received by a government, belonging to intergovernmental assistance. Foreign loans generally have a relatively long repayment period and the interest rate is low as only $2 \%-3 \%$. 2016, the China Development Bank has accumulated 1.6 billion dollars to support 19 projects in Laos that entailed to become the "second largest bank" in Laos.

\section{2) International Bank Loans}

In the international financial markets borrowing money raise funds. Most of the times are financial participant's foreign commercial banks and foreign institutions than international financial organizations - from the Asian Infrastructure Investment Bank, the World Bank, and so on. For instance - February 8, 2017, the Lao Ministry of Finance to the World Bank loan 25 million US dollars for the Lao national road construction of the second phase of the project, as well as in the country for road maintenance and expansion.

\section{F. Leasing financing}

Lao leasing financing industry is not very developed, most of the leasing companies are subordinate institutions of the bank associations. The lessor is essentially a creditor in the transaction to rental equipment, equipment maintenance, personnel training and other service business. Financial leasing for enterprises to open up a new financing channels, through the combination of financing the new situation, not only to improve the production equipment and technology introduction speed, but also can save money to use and improve the enterprise's capital utilization.

\section{MAIN FINANCING MODEL ANALYSIS}

\section{A. $E P C$}

It refers to the company which is entrusted by the owner undertakes the whole process or some stages of the project design, procurement, construction, commissioning in accordance with the contract.

TABLE I. EXAMPLE OF EPC

\begin{tabular}{|l|c|}
\hline Name of project & Renovation of Vientiane Highway in Laos \\
\hline Quantity of Engineering & $23.697 \mathrm{~km}$ and $4.979 \mathrm{~km}$ \\
\hline Total investment & $\$ 71$ million \\
\hline Duration & 3 years \\
\hline signing the contract & May 2015 \\
\hline The way of the loan & Concessions of the Chinese government \\
\hline
\end{tabular}

Usually, the company is responsible for the quality, safety, cost and progress of the contracted project under the condition of total price contract. Investment cases of China in Laos:

Schema map:

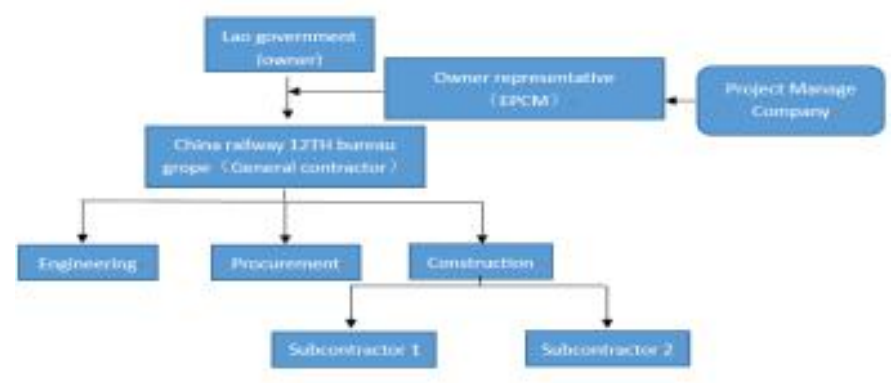

Fig. 2. Schema map of EPC

In the turnkey project, the government invested heavily in Finance, but the Laotian government is of limited fund. Through this model, the enterprise has great control over the project, less design change, shorter construction period and shorter capital cycle.

\section{B. BOT}

The infrastructure in Laos is relatively backward due to lack of funds from the government. Therefore, through BOT project financing, it will play a big role. B0T can not only raise funds through project financing, but also raise funds through company financing, Item Company uses the concession agreement to obtain financing, and make use of the project benefits to repay debt and operating expenses in the concession period of the project, thus getting profit. After the expiration of the franchise, the project is transferred to the government of the host country or its affiliates at a certain price or gratis, more than $80 \%$ of the large infrastructure projects in Laos are funded through BOT projects, but this program is more complicated and of long time. The early period of the project is too long and the financing costs are high, and more participants, companies will bear greater risks. Investment cases of China in Laos:

TABLE II. EXAMPLE OF BOT

\begin{tabular}{|c|c|}
\hline Name of project & Construction of Expressway to Vientiane \\
\hline Quantity of Engineering & $1250 \mathrm{~km}$ \\
\hline Total investment & $\$ 1.4$ billion \\
\hline Sponsor of the project & Yunnan Construction Engineering Group \\
& Co., Ltd. \\
\hline Current stage & Feasibility study \\
\hline
\end{tabular}

In this project, the item company selects sources of financing according to the characteristics of the project and the company's situation. After the Laotian government releases 
information and publicly bids for the BOT project, the winning Chinese enterprise or the consortium of many of its businesses is the initiator. The sponsor is responsible for the whole project. When a sponsor starts a BOT project, usually one or more sponsors form a limited liability company with a specific goal, which is the BOT item company.

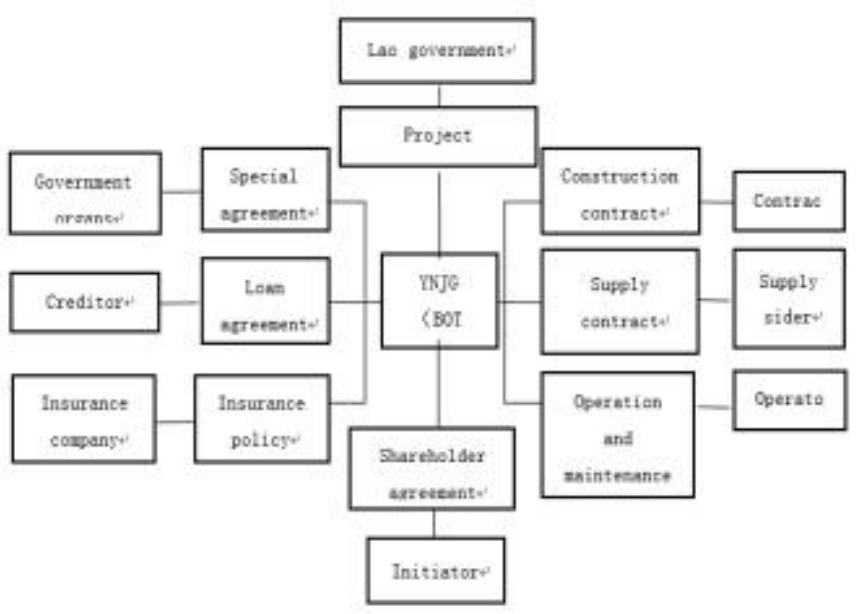

Fig. 3. Schema map of BOT

\section{C. $P P P$}

PPP is a kind of investment and financing mode between the public sector and private enterprises. The Special Purpose Company is usually composed of the Laotian government and the winning enterprises and then sign a concession contract, the SPC is responsible for the entire project financing, construction and operation. Through the PPP, the government can obtain the same proportion of income in the project operation phase according to the proportion of capital input, this is a win-win cooperation model. The Laotian government has limited financial and technological capacity, therefore, the PPP model is more widely used in infrastructure construction projects. Schema map:

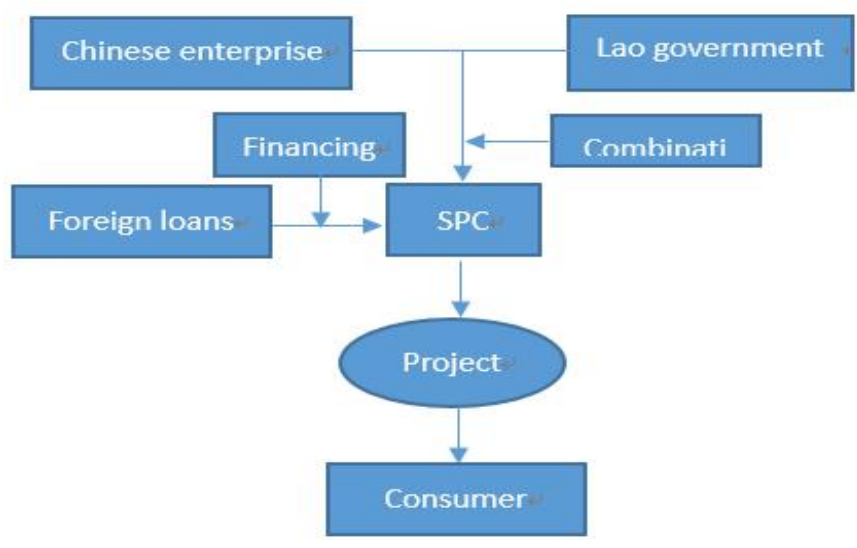

Fig. 4. Schema map of PPP

In this project, SPC is composed of Chinese enterprises and Laotian government, and responsible for the project according to the proportion of investment. At the same time, all income and expenses are enjoyed and borne by SPC. Suppose that the total investment of the joint venture between the Laotian government and the Chinese enterprises is $30 \%$, in this part of the capital, Chinese enterprises and the Laotian government invest $50 \%$ each. The remaining $70 \%$ of the project's total investment comes from debt financing. During the operation period, SPC both sides undertake the corresponding debts and enjoy the benefits in proportion to the investment. The management of the agreement will be handed over to the local government of Laos after the expiration of the agreement.

\section{ADVICE ON FINANCING}

\section{A. Make the best of financial resources in Laos}

Phannakone,(2012) [4] notes that enterprises can use government finance for project development, thus eliminating part of the loan procedures and interest, reducing financing ratio and capital recovery cycle.

\section{B. Make the best of securities markets outside Laos}

Due to the limitations of financial system in Laos, the securities market is not perfect. It is difficult for enterprises to raise funds through the direct financing channels of issuing stocks and bonds, so the enterprises can make full use of the securities market outside Laos for financing, The way of securities financing can not only improve the company's credit level, but also reduce the company's debt ratio, it is the main way to raise equity capital in modern enterprises and projects.

\section{Bank lending in Laos}

The commercial banks in Laos are becoming more and stricter in credit management, the adjustment of the bank credit structure is accelerating and requirements of raising the loan for enterprises is stricter. But in recent years, from $\mathrm{Xi}$ Penghan (2015) [7], Laos has been actively promoting foreign investment and the lending rates have been lowered, enterprises can finance through the favorable banking policies of Laos.

\section{CONCLUSIONS}

The economy and infrastructure is relatively backward in Laos, Under the background of the Belt and Road, investment in road infrastructure of Laos is getting more and more widespread attention of Chinese enterprises.. This paper analyzes the financing situation of highway infrastructure in Laos, thus we know the main source of funds and the main financing mode of China's investment in Laotian project, and it is convenient for us to have a better understanding of the investment environment in Lao.

\section{ACKNOWLEDGMENT}

Thanks for my postgraduate tutor and members of the anonymous reviewers for helpful comments and suggestions. Thanks Friends and family for their support. 


\section{REFERENCES}

[1] Lao People's Democratic Republic Annual Report, 2015.

[2] Lao People's Democratic Republic Montary Statistics Report Q3.2016

[3] China's Ministry of Commerce Laos Country Guide, 2016.

[4] Phannakone, "Phanyoulath Laos to attract China direct investment in environmental analysis," Hunan University, 2012.
[5] E.R. Liu, Q.M. Liu, and W. Zhou, "Transportation infrastructure investment in South East Asia and South Asia (laos),"Economic Science Press, 2016

[6] P.L. Guo, and H. Li, "Financing methods and Countermeasures of Laos Enterprises," Journal of China Hi-Tech Enterprises, 2010.

[7] P.H. Xi, "Analysis of Highway Development Pattern between China and Laos,” Economic Science Press, 2015. 